Three main areas were selected for seismic work, all situated on the landward margin of the sedimentary cover rocks towards basement. Work commenced in early July on south Nûgssuaq, where basement was to be traced from the south across the Sarqaq valley fault for approximately $30 \mathrm{~km}$ north-westwards along the coast. The second project was to investigate the Ikorfat fault on the north coast of Nûgssuaq, and the operations were concluded in the first week of August with a survey in the Itsako area of southern Svartenhuk Halvø.

\title{
References
}

GGU 1973: Geological results of the 1971 expedition to central West Greenland. Rapp. Grønlands geol. Unders. 53, 37 p.

Hald, N. 1973: Preliminary results of the mapping of the Tertiary basalts in western Nûgssuaq. Rapp. Grønlands geol. Unders. 53, 11-19.

Henderson, G. 1972: Geological and geophysical work in central West Greenland. Rapp. Grønlands geol. Unders. 45, 15-20.

Henderson, G. 1973: Geological and geophysical work in the Nûgssuaq-Disko region, central West Greenland. Rapp. Grønlands geol. Unders. 55, 18-20.

Jürgensen, T. \& Mikkelsen, N. (in press): Onset of the Tertiary volcanism in the Nûgssuaq area, West Greenland as dated by coccoliths. Submitted to Bull. geol. Soc. Denmark.

Rosenkrantz, A. 1970: Marine Upper Cretaceous and lowermost Tertiary deposits in West Greenland. Bull. geol. Soc. Denmark 19, 406-453.

\section{UNTRADITIONAL TOPOGRAPHIC MAPPING IN CENTRAL WEST GREENLAND}

\author{
Keld S. Dueholm
}

During the geological investigations carried out in central West Greenland (see Schiener, this report) a cartographical programme was carried out to test a newlydeveloped method of producing topographic maps direct from aerial photographs. The programme was adapted to the working conditions of the geologists and the author was attached to different geological parties working on western and central Nûgssuaq, southern Disko, Hareøen and Ubekendt Ejland. Within the two months' season sufficient measurements were obtained to enable eventual topographic map coverage of $1700 \mathrm{~km}^{2}$ with acceptable accuracy for geological mapping at the scale 1: 50000 .

\section{Principles}

The nature of the terrain and the unstable climate, coupled with logistic difficulties in many parts of Greenland, make the establishment of the complete ground control network necessary for traditional photogrammetric mapping, 
problematical to achieve. Conventional measuring of a coherent fixed-point system seems an impossible task within the present framework of time and economy. In the method used here, the field observations are made independently and the relationships between these measurements are established later by means of photogrammetric treatment.

Hitherto nothing has been published on the method used this summer, but a detailed description of the mapping technique and a new digital measuring system will be available by late spring 1974 .

\section{Aim}

The aim of the method is to enable one man, possibly the geologist or assistant himself, to conduct the topographic mapping, parallel with normal geological investigations.

By adapting the accuracy of the mapping to geological needs, relatively cheap and quick instrumentation can be used in the field work as well as in the subsequent photogrammetric work. Systematisation of methods will enable most of the map production to be conducted without the assistance of a photogrammetric expert.

\section{Field work}

Measurements made in the field consisted of normal theodolite distance, and vertical and horizontal angle determinations, astronomical fixes and barometric and trigonometric altitude determinations. They can be classified as follows:

(1) Scale control: Determination of distances between random points. Approximately one distance per four photogrammetric models.

(2) Plane rotation control: Determination of horizontal angle between three random points.

(3) Height control: Barometric level determination. Trigonometric measurements of altitude differences. Approximately one height fixed point per photogrammetric model.

(4) Plane fixed points: Astronomical determination of geodetic latitude and longitude. Approximately two points per fifty photogrammetric models.

\section{Data processing}

The independent ground control data are computed together with an analytical aero-triangulation using the least square adjustment. The aero-triangulation can be performed with sufficient accuracy in a newly developed digital photogrammetric measuring system, consisting of a slightly rebuilt Hilger and Watts mirror stereoscope, where the digital model formation is guided and calculated by a table computer. 


\section{Application}

The result of the data processing is a coherent net of plane and height fixedpoints distributed throughout the mapped area so that each photogrammetric model can be rectified and scale determined. Thus in addition to the topographic mapping, the geologist is able to perform quantitative geological photogrammetry directly from the aerial photographs. Such determinations can be done using the digital measuring system mentioned above.

\section{Compilation of maps}

The drawing of the topographic contour map can be profitably accomplished at the same time as the final drawing of the geological map. A Zeiss 'Double Projector' gives the accuracy needed and provides the complete model as essential for photo-interpretation. The time saved to geologists by working with an analogical drawing instrument instead of simple transference instruments (Sketchmaster, Stereosketch, Radial Plotter, Stereotop etc.) will probably equal the time spent on contour drawing (which can be done by an assistant).

\section{Tolerances}

The experiments of this summer have been performed with the following tolerances (based on aerial photographs on a scale of 1:40 000).

(1) The relative error in plane and height is less than $5 \%$, i.e. all measurements of distances and altitude differences are within the above limits of error.

(2) The absolute mean error in height, e.g. in relation to the centre of the earth, is 5 metres.

(3) The error in global connection is less than $200-400$ metres. This error is due to the astronomical observations and may seem gross. However, the error involves a displacement of the entire map, the scale not being affected, and thus the relative geological conclusions remain the same. From a geological point of view, the error is insignificant. The error is unacceptable for legal purposes, e.g. for fixing boundaries of concession units. In such cases more accurate astronomical observations or better satellite observations are essential.

The tolerances described here concern this particular mapping experiment. The theory behind the methods will meet other and more accurate requirements, but this only involves a re-evaluation of the instruments used and possibly a different scale of aerial photographs.

Instituttet for Landmåling og Fotogrammetri,

Danmarks Tekniske Højskole, Landmålervej 7 , 2800 Lyngby. 